\title{
Synthesis of 3-Hydroxy-1-(p-methoxyphenyl)-2-methylpyridine-4-one and Spectrophotometric Extraction Studies on its Complexation of Vanadium(V)
}

\author{
Vesna Petrović Peroković,* Astrid Gojmerac Ivšić, Željka Car, and Srđanka Tomić \\ Department of Chemistry, Faculty of Science, University of Zagreb, Horvatovac 102a, HR-10000 Zagreb, Croatia
}

Abstract. In this paper a single step synthesis of 3-hydroxy-1-(p-methoxyphenyl)-2-methylpyridine-4-one (HM) using starting maltol and $p$-anisidine in the presence of acid catalyst ( $p$-toluenesulfonic acid or $\mathrm{HCl}$ ) is described. The reaction is carried out by heating the aqueous solution of the reactants and a catalyst in a sealed thick-walled glass tube at $150{ }^{\circ} \mathrm{C}$ at different reaction times in order to retrieve an optimal yield. The complexation reactions of vanadium(V) with $\mathrm{HM}$ as well as the extraction of $\mathrm{V}(\mathrm{V})$ from aqueous to organic phase were studied spectrophotometrically. The optimum conditions for extraction of vanadium(V) from aqueous phase, containing chloride or thiocyanate ions, to chloroform solution of HM and complex formation have been evaluated. Based on the results obtained by Job's and equilibrium shift methods the composition of the complexes has been found to be $\mathrm{V}(\mathrm{V}): \mathrm{Cl}(\mathrm{SCN}): \mathrm{HM}=1: 1: 2$.

Keywords: 3-hydroxy-1-(p-methoxyphenyl)-2-methylpyridine-4-one, spectrophotometric extraction, vanadium complexes

\section{INTRODUCTION}

3-Hydroxypyridine-4-ones (3,4-HPOs) are a well known class of heterocyclic compounds extensively studied due to their broad field of application. They possess strong chelating properties especially towards $\mathrm{M}(\mathrm{II}) / \mathrm{M}(\mathrm{III})$ ions, which is the basis for their applications as therapeutics ${ }^{1}$ as well as selective extractants for certain metals. ${ }^{2-5}$ So far, because of their chelating abilities, this group of compounds have shown the most promising results in the treatment of metal overload in humans ${ }^{1-4,6}$ but they are not exclusive to such and similar therapies. Their potential as possible antibacterial ${ }^{7}$ and antiviral ${ }^{8}$ drugs has also been recognized and since they are especially selective to Fe(III) they are increasingly tested as plausible antiproliferative agents ${ }^{1,9}$ too. Preparative procedures of 3,4-HPOs are mostly characterized by moderate to low yields as well as prolonged reaction times and sometimes difficult isolation from the reaction mixtures. ${ }^{3,4,10,11}$ Thus, research invested in the optimization of their preparative procedures to achieve better yields in the simplest possible synthetic route is imperative in order to meet high demands for these compounds created by their more increasing and extensive field of application.
Vanadium is widely distributed in nature. ${ }^{12}$ It occurs at very low levels in natural waters, in the atmosphere and also in living organisms. In the environment vanadium occurrs in the $(\mathrm{V})$ oxidized form, but in the body it can undergo changes in oxidation states and it can also bind with blood protein, transferrin. ${ }^{13}$ It plays an important role in physiological systems including normalization of sugar levels and it has been reported that some vanadium complexes with pyran-4one and pyridin-4-one derivatives are suitable compounds for treatment of type 2 diabetes. ${ }^{14,15}$ In trace amounts vanadium represents an essential element for normal cell growth, but can be toxic when present in higher concentrations. The toxic action is largely confined to the respiratory tract ${ }^{16}$ but it can also cause anaemia, reproductive toxicity in males and affect vision. Vanadium participates in various enzyme systems. It acts as an inhibitor or cofactor of the oxidation of amines, ${ }^{17}$ and stimulates a variety of enzymes ${ }^{12}$ including glyceraldehyde-3-phophate dehydrogenase, tyrosine phos-phorylase, glycogen synthase, lipoprotein lipase, glucose-6-phosphate dehydrogenase etc. Several chelators had been previously examined as possible agents in the treatment or prevention of vanadium overload in the organism. ${ }^{18}$

\footnotetext{
* Author to whom correspondence should be addressed. (E-mail: vpetrovi@chem.pmf.hr)
} 
In continuation of our work on the synthesis and properties of 3,4-HPO derivatives ${ }^{11,19,20}$ and research in the field of coordinating capabilities of vanadium complexes $^{21}$ we report a single step synthesis of 3-hydroxy1-(p-methoxyphenyl)-2-methylpyridine-4-one (HM) which we optimized by using the adequate catalyst and appropriate reaction time to obtain the most satisfactory yield. Detailed spectrophotometric studies of the extraction of vanadium(V) with HM from water solutions into chloroform are also described. The preliminary results presented in this work will be used for the development of a simple extractive-spectrophotometric method for the determination of trace amounts of vanadium in biological and environmental samples.

\section{EXPERIMENTAL}

\section{Materials and Methods for Synthesis of HM}

The starting chemicals, 3-hydroxy-2-methylpyran-4-one (maltol) and $p$-methoxyaniline ( $p$-anisidine), were purchased from Aldrich Corp., and $p$-toluenesulphonic acid ( $p$-Ts $\mathrm{OH})$ from Merck. All solvents were purified using standard procedures. Thin layer chromatography (TLC, solvents and proportions are given in the text) was performed on Fluka silica gel (60 F 254) plates $(0.25 \mathrm{~mm})$. Visualization was effected by the use of UV light at 254 nm. Melting point was determined in open capillary using Büchi B-540 melting point apparatus and is uncorrected. IR spectrum was recorded using Perkin Elmer FT-IR Spectrometer Spectrum Two. ${ }^{1} \mathrm{H}$ and ${ }^{13} \mathrm{C}$ NMR spectra were recorded with Bruker Avance spectrometer at room temperature at $600.130 \mathrm{MHz}$ and $150.903 \mathrm{MHz}$, respectively. Chemical shifts are given in ppm downfield from TMS as internal standard. Electrospray ionization mass spectrometry (ESI-MS) was performed using Agilent $6410 \mathrm{MS}$ instrument. CHN elemental analysis was carried out by the Analytical Service Laboratory of the Ruđer Bošković Institute.

\section{3-Hydroxy-1-(p-methoxyphenyl)-2-methylpyridine- 4-one (HM)}

A mixture of maltol $(1 \mathrm{~g}, 7.93 \mathrm{mmol}), p$-anisidine $(0.98$ $\mathrm{g}, 7.93 \mathrm{mmol})$ and $p$-TsOH $(150 \mathrm{mg}, 0.79 \mathrm{mmol})$ in water $(20 \mathrm{~mL})$ was heated $\left(150{ }^{\circ} \mathrm{C}\right)$ in a sealed thickwalled glass tube for $8 \mathrm{~h}, 24 \mathrm{~h}, 48 \mathrm{~h}$ and $72 \mathrm{~h}$. In the case of $\mathrm{HCl}(67 \mu \mathrm{L}, 0.79 \mathrm{mmol})$ as a catalyst instead of $p$-TsOH the reaction mixture was heated for $48 \mathrm{~h}$. The crude product, obtained by cooling the reaction mixtures to room temperature, was collected by filtration. It was recrystallized from methanol yielding light brown crystals $(29 \%, 63 \%, 65 \%$ and $64 \%$, respectively, with $p$ $\mathrm{TsOH}$ as a catalyst, $52 \%$ in the case of $\mathrm{HCl}$ as a catalyst). $R_{\mathrm{f}}=0.44$ (ethyl acetate/methanol, 5:1). M.p. 245.5-247.7 ${ }^{\circ} \mathrm{C}$; lit. $^{10} 249^{\circ} \mathrm{C}$.
${ }^{1} \mathrm{H}$ NMR (DMSO- $\left.d_{6}\right) \delta /$ ppm: $1.95\left(\mathrm{~s}, 3 \mathrm{H}, \mathrm{CH}_{3}\right), 3.83$ (s, $\left.3 \mathrm{H}, \mathrm{OCH}_{3}\right), 6.19$ (d, $\left.1 \mathrm{H}, J=7.3 \mathrm{~Hz}, \mathrm{H}-5\right), 7.07$ (d, 2 $\mathrm{H}, J=8.8 \mathrm{~Hz}, \mathrm{CH}-\mathrm{Ar}), 7.36$ (d, $2 \mathrm{H}, J=8.8 \mathrm{~Hz}, \mathrm{CH}-$ Ar), 7.49 (d, $1 \mathrm{H}, J=7.3 \mathrm{~Hz}, \mathrm{H}-6)$.

${ }^{13} \mathrm{C}$ NMR (DMSO- $\left.d_{6}\right) \delta / \mathrm{ppm}: 13.18\left(\mathrm{CH}_{3}\right), 55.38$ $\left(\mathrm{OCH}_{3}\right), 110.50$ (C-5), $114.48(2 \mathrm{CH}, \mathrm{Ar}), 128.00$ (2 $\mathrm{CH}$, Ar), 128.79 (C-2), $134.41(\mathrm{C}-\mathrm{N}), 138.03$ (C-6), $144.79(\mathrm{C}-3), 159.18\left(\underline{\mathrm{C}}-\mathrm{OCH}_{3}\right), 169,38(\mathrm{C}=\mathrm{O})$.

ESI-MS: $m / z[\mathrm{M}+\mathrm{H}]^{+} 232.1$.

IR $(\mathrm{KBr}) \quad v_{\max } / \mathrm{cm}^{-1}: 3160(\mathrm{O}-\mathrm{H}), 3053,3003$ $\left(\mathrm{C}-\mathrm{H}_{\text {arom. }),}\right.$ 2936, $2932\left(\mathrm{C}-\mathrm{H}_{\mathrm{s}}\right), 2838\left(\mathrm{C}-\mathrm{H}_{\mathrm{as}}\right), 1624$ $(\mathrm{C}=\mathrm{O}), 1575,1508\left(\mathrm{C}=\mathrm{C}_{\text {arom. }}\right), 1302(\mathrm{C}-\mathrm{N}), 1250,1033$ $(\mathrm{C}-\mathrm{O}-\mathrm{C})$.

Anal. Calcd. mass fraction of elements, $w / \%$, for $\mathrm{C}_{13} \mathrm{H}_{13} \mathrm{NO}_{3}\left(M_{\mathrm{r}}=231.25\right)$ are: $\mathrm{C} 67.52, \mathrm{H} 5.67, \mathrm{~N} 6.06$, found: C 67.62, H 5.72, N 6.00.

\section{Reagents and Apparatus for Spectrophotometric Measurements}

The stock solution of vanadium(V) $(0.01 \mathrm{M})$ was prepared by dissolving $1.17 \mathrm{~g}$ of ammonium vanadate $\left(\mathrm{NH}_{4} \mathrm{VO}_{3}\right.$ p.a., Kemika) in deionized water and making up to a volume of 1 liter. The solution was standardized gravimetrically with cupferron. ${ }^{22}$ The solutions of HM prepared by dissolving weight amount of the compound in chloroform served as the organic phase for extraction. All other chemicals used were of analytical reagent grade. The $\mathrm{pH}$ of the solutions was adjusted with $\mathrm{HCl}$ or $\mathrm{HNO}_{3}$. $\mathrm{LiCl}$ and $\mathrm{KSCN}$ were used to achieve a required concentration of chloride and thiocyanate ions.

A Varian double-beam spectrophotometer, Model Cary 3, equipped with 1-cm quartz cells, was used to determine absorption spectra and perform absorbance measurements. Acidity was measured with Radiometer PHM 85 Precision $\mathrm{pH}$-meter provided with a combined glass- $\mathrm{Ag} / \mathrm{AgCl}$ electrode. A Griffin flask shaker with a time switch served for extraction.

\section{Extraction Procedure}

To an aliquot of the aqueous solution containing $5 \times 10^{-5}$ mol dm ${ }^{-3}$ vanadium(V) an appropriate amount of other components were added in amounts needed to achieve the derived condition. The resulting solutions were diluted with deionized water to a total volume of $5 \mathrm{~cm}^{3}$. The solution was extracted with $5.0 \mathrm{~cm}^{3}$ of $\mathrm{HM}$ dissolved in chloroform, and then shaken with a mechanical shaker in a $50 \mathrm{ml}$ conical flask for $20 \mathrm{~min}$. After the phases were separated by gravity, absorption spectra of the organic phase were recorded between 350 and 800 $\mathrm{nm}$ as compared to a blank reagent prepared under the same experimental conditions.

The shaking time of the aqueous and organic phases of $20 \mathrm{~min}$ was sufficient to achieve reproducible 


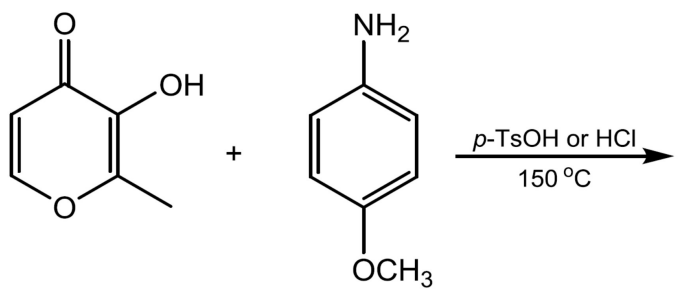<smiles>COc1ccc(-n2ccc(=O)c(O)c2C)cc1</smiles>

\begin{tabular}{r|c|c}
\multirow{2}{*}{$t / h$} & \multicolumn{2}{|c}{$\mathrm{HM} / \%$} \\
\cline { 2 - 3 } & $p$ - TsOH & $\mathrm{HCl}$ \\
\hline 8 & 29 & - \\
24 & 63 & - \\
48 & 65 & 52 \\
72 & 64 & -
\end{tabular}

Scheme 1. Preparation of 3-hydroxy-1-(p-methoxyphenyl)-2-methylpyridine-4-one (HM) at different reaction times and acid catalysts.

results by measuring extracted vanadium in the organic phase by absorption spectrometry. The absorbance at maximum wavelength remained stable for at least 2 hours.

Vanadium concentration in the aqueous phase after extraction were calculated from the difference between the maximum and constant absorbance of the organic phase at $525 \mathrm{~nm}(650 \mathrm{~nm})$ at optimum conditions for extraction $\left(A_{0}\right)$ and the measured absorbance value before reaching complete complex formation in the organic phase $\left(A_{\mathrm{x}}\right)$.

\section{RESULTS AND DISCUSSION}

\section{Synthesis}

This paper describes a single step synthesis of 3hydroxy-1-( $p$-methoxyphenyl)-2-methylpyridine-4-one (HM) using 3-hydroxy-2-methylpyran-4-one (maltol) and $p$-methoxyaniline ( $p$-anisidine) as starting materials (Scheme 1). The reaction of a primary alkyl or aryl amines with 3-hydroxypyran-4-one derivatives that forms $\mathrm{N}$-substituted 3-hydroxypyridine-4-ones is known. Its mechanism belongs to the Micheal-type addition. ${ }^{4}$ Double attack of the nucleophilic amino group at both $\alpha, \beta$-unsaturated functions on the pyran-4one molecule with the loss of a water molecule leads to the formation of pyridine-4-one. ${ }^{4}$ Under the basic conditions employed in the amination step, 3-hydroxyl group on the pyran-4-one undergoes a side reaction which results in the formation of the byproduct and decreased overall yield. ${ }^{3,4}$ There are two possibilities to avoid a secondary reaction: protection of 3-hydroxyl group of pyran-4-one by ether formation (the Harris method) ${ }^{23}$ or, as in our case, to use an acidic catalyst, which is usually $\mathrm{HCl}^{3,10}$ It should be noted that, in acidic conditions, the aryl amines are not completely protonated and act as nucleophiles.
The conditions for 3-hydroxypyridine-4-one synthesis often require heating of the reaction mixture, usually at reflux, for an extended period of time (3-7 days). ${ }^{3,4,10,11}$ The synthesis of HM by refluxing the reaction mixture of maltol and $p$-anisidine in a diluted $\mathrm{HCl}$ solution for $72 \mathrm{~h}$, described by Zhang et al., ${ }^{10}$ gave HM in $58 \%$ yield. The preparation of the pyridinone derivatives, as well as HM, by heating the aqueous reaction mixtures without the addition of a catalyst in a sealed thick-walled glass tube for a shorter time (2 days) is also a well established literature procedure. ${ }^{15}$ Bearing all this in mind, we carried out the synthesis of HM by heating aqueous solution of the reactants (in an equimolar ratio) and the acid catalyst $(0.1$ equiv. $)$ in a sealed thickwalled glass tube at $150{ }^{\circ} \mathrm{C}$. $p$ - $\mathrm{TsOH}$ and $\mathrm{HCl}$ were used as the acid catalysts giving $\mathrm{HM}$ in $65 \%$ and $52 \%$, respectively after 2 days of heating. A slight increase in the yield of the product only in the case of $p$-TsOH $(65$ $\%$ ) compared to the synthesis without the catalyst (56 $\%)^{15}$ was detected. After that, an influence of the duration of the reaction catalysed by $p-\mathrm{TsOH}$ on the yield was tested. The reaction mixtures were heated for $8 \mathrm{~h}$, $24 \mathrm{~h}, 48 \mathrm{~h}$ and $72 \mathrm{~h}$ yielding HM in $29 \%, 63 \%, 65 \%$ and $64 \%$, respectively. It can be concluded that the optimal reaction time for the preparation of HM in the above mentioned conditions is $24 \mathrm{~h}$ and that the reaction time extension does not affect the yield of the product significantly. Compared with the known data for HM synthesis, ${ }^{10,15}$ the most important benefit of the described procedure is a significant reduction of the reaction time ( 1 day compared to $2^{15}$ or $3^{10}$ days). The isolation and the purification of HM was performed only by filtration and recrystallization. The product was fully characterized using standard spectroscopic methods. Since 3,4-HPOs have shown a broad field of potential applications, these reaction conditions can be useful in the syntheses of their various derivatives in our future studies. 


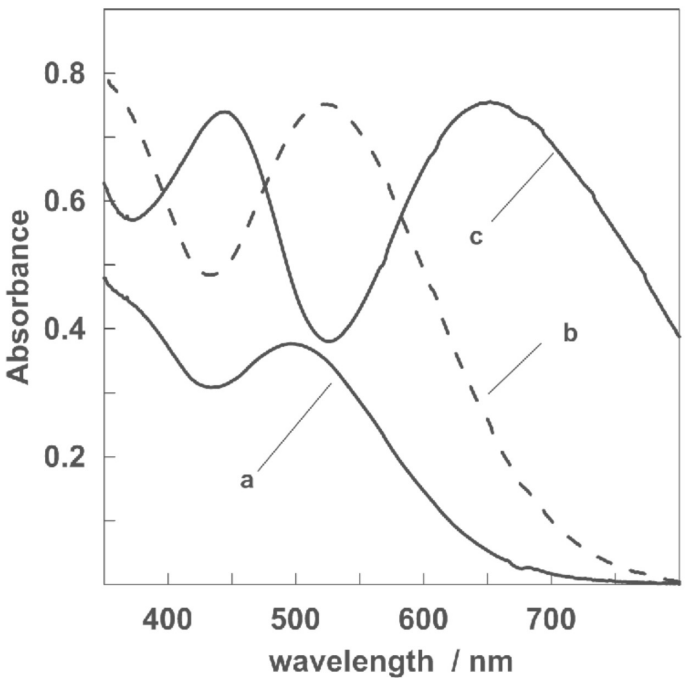

Figure 1. Absorption spectra of vanadium(V)-HM complex in chloroform. $c(\mathrm{HM})=2 \times 10^{-3} \mathrm{~mol} \mathrm{dm}^{-3}$; $\mathrm{pH} 2$; a) $c\{\mathrm{~V}(\mathrm{~V})\}=$ $2 \times 10^{-4} \mathrm{~mol} \mathrm{dm}^{-3}$ without presence of chloride and thiocyanate ions; b) $c\{\mathrm{~V}(\mathrm{~V})\}=2 \times 10^{-4} \mathrm{~mol} \mathrm{dm}^{-3}, c\left(\mathrm{Cl}^{-}\right)=2 \mathrm{~mol} \mathrm{dm}^{-3}$; c) $c\{\mathrm{~V}(\mathrm{~V})\}=1 \times 10^{-4} \mathrm{~mol} \mathrm{dm}^{-3}, c\left(\mathrm{SCN}^{-}\right)=2 \times 10^{-2} \mathrm{~mol} \mathrm{dm}^{-3}$.

\section{Optimum Conditions for Vanadium Extraction}

Vanadium(V) reacts with HM in acidic medium, regardless of the kind of mineral acid used, giving the complex which is extracted with chloroform. A well defined maximum at $500 \mathrm{~nm}$ was observed in the spectra if extraction was carried out from solutions without the presence of chloride ions. The increase in sensitivity and the batochromic shift to $525 \mathrm{~nm}$ was observed if vanadium $(\mathrm{V})$ was extracted from the solution containing an excess of chloride ions $\left(2 \mathrm{~mol} \mathrm{dm}{ }^{-3}\right)$. However, the vanadium(V) complex extracted from acid solutions containing an excess of thiocyanate ions $\left(2 \times 10^{-2} \mathrm{~mol}\right.$ $\mathrm{dm}^{-3}$ ) gave green complexes which had maxima at 440 and $650 \mathrm{~nm}$ (Figure 1).

Dependence of acidity on absorbance of $\mathrm{V}(\mathrm{V})-\mathrm{HM}$ complex was investigated by varying $\mathrm{HCl}$ or $\mathrm{HNO}_{3}$ in the presence of an excess of chloride $\left(2 \mathrm{~mol} \mathrm{dm}^{-3}\right)$ or thiocyanate ions $\left(2 \times 10^{-2} \mathrm{~mol} \mathrm{dm}^{-3}\right)$ using optimal concentration of $\mathrm{HM}\left(2 \times 10^{-3} \mathrm{~mol} \mathrm{\textrm {dm } ^ { - 3 }}\right)$. The obtained results showed that the absorbance of the organic phase was maximal when $\mathrm{pH}$ value of the aqueous phase was 2 for vanadium complex when extracted in the presence of an excess of chloride ions as well as for vanadium complex when extracted in the presence of an excess of thiocyanate (Figure 2).

The effects of HM concentration on the extraction of vanadium $(\mathrm{V})$ at optimum acidity were also studied. The reagent concentration was varied within the range $1 \times 10^{-5}$ $-5 \times 10^{-4} \mathrm{~mol} \mathrm{dm}^{-3}$, and the absorbance of organic phase was measured at $525 \mathrm{~nm}$ and $650(440) \mathrm{nm}$ respectively. The maximum and constant absorbance of the organic

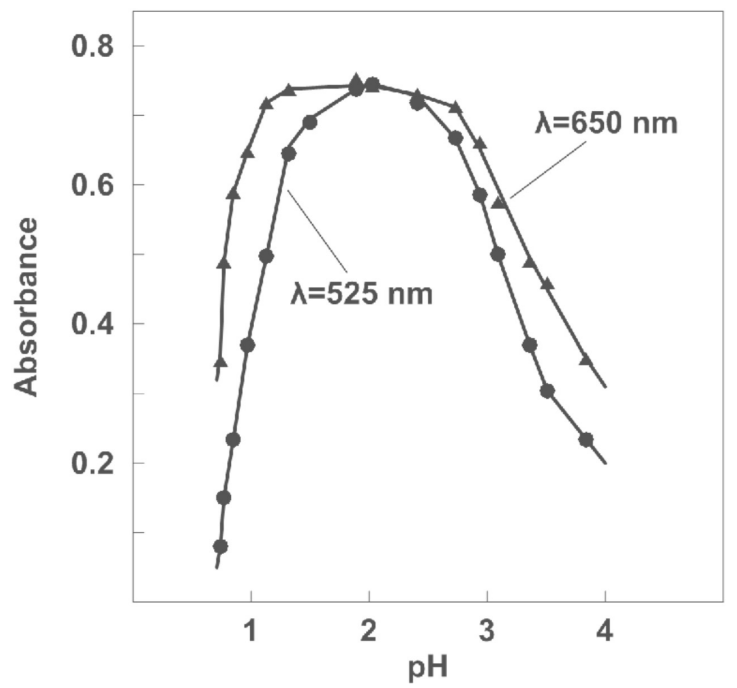

Figure 2. Effect of $\mathrm{pH}$ on absorbance of vanadium(V)-HM complex. $c(\mathrm{HM})=2 \times 10^{-3} \mathrm{~mol} \mathrm{dm}^{-3} ; \mathrm{pH} 2 ; \bullet c\{\mathrm{~V}(\mathrm{~V})\}=$ $2 \times 10^{-4}, c\left(\mathrm{Cl}^{-}\right)=2 \mathrm{~mol} \mathrm{dm}^{-3} ; \boldsymbol{\Delta} c\{\mathrm{~V}(\mathrm{~V})\}=1 \times 10^{-4} \mathrm{~mol} \mathrm{dm}^{-3}$, $c\left(\mathrm{SCN}^{-}\right)=2 \times 10^{-2} \mathrm{~mol} \mathrm{dm}^{-3}$

phase was achieved with 10-fold excess of the reagent for extraction (Figure 3). In further studies, a $2 \times 10^{-3} \mathrm{~mol} \mathrm{dm}^{-3}$ HM solution in chloroform was used in both cases.

The influence of chloride as well as thiocyanate ion concentration on the extraction of vanadium(V) was examined by varying concentration of these ions in the aqueous phase at $\mathrm{pH}$ 2. Extractions started from chloride or thiocyanate ion solutions containing the analytical vanadium(V) concentration $2 \times 10^{-4} \mathrm{~mol} \mathrm{dm}^{-3}$ and

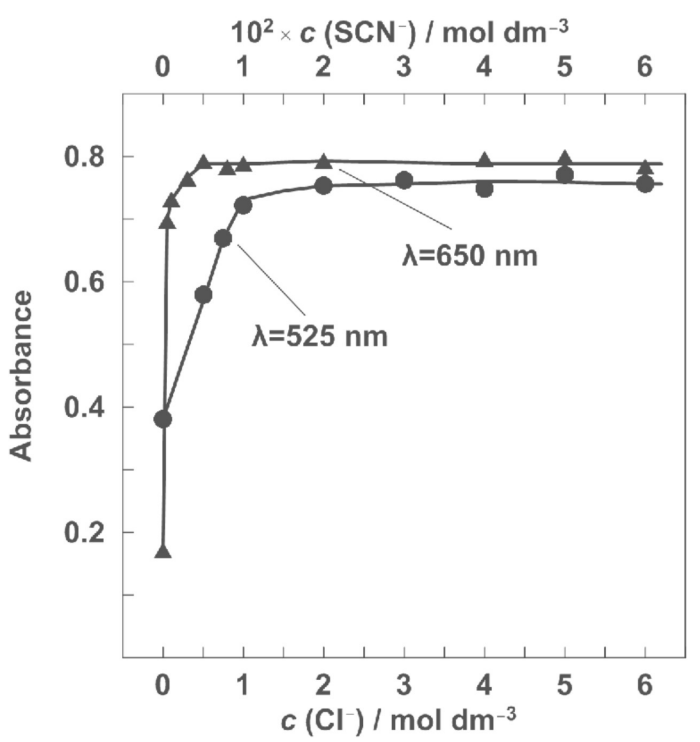

Figure 3. The dependence of the absorbance of $\mathrm{V}(\mathrm{V})-\mathrm{HM}$ complex on HM concentration. pH 2; $\bullet\{\mathrm{V}(\mathrm{V})\}=2 \times 10^{-4}$ $\mathrm{mol} \mathrm{dm}{ }^{-3}, c\left(\mathrm{Cl}^{-}\right)=2 \mathrm{~mol} \mathrm{dm}^{-3} ; \boldsymbol{\Delta} c\{\mathrm{~V}(\mathrm{~V})\}=1 \times 10^{-4} \mathrm{~mol}$ $\mathrm{dm}^{-3}, c\left(\mathrm{SCN}^{-}\right)=2 \times 10^{-2} \mathrm{~mol} \mathrm{dm}^{-3}$. 


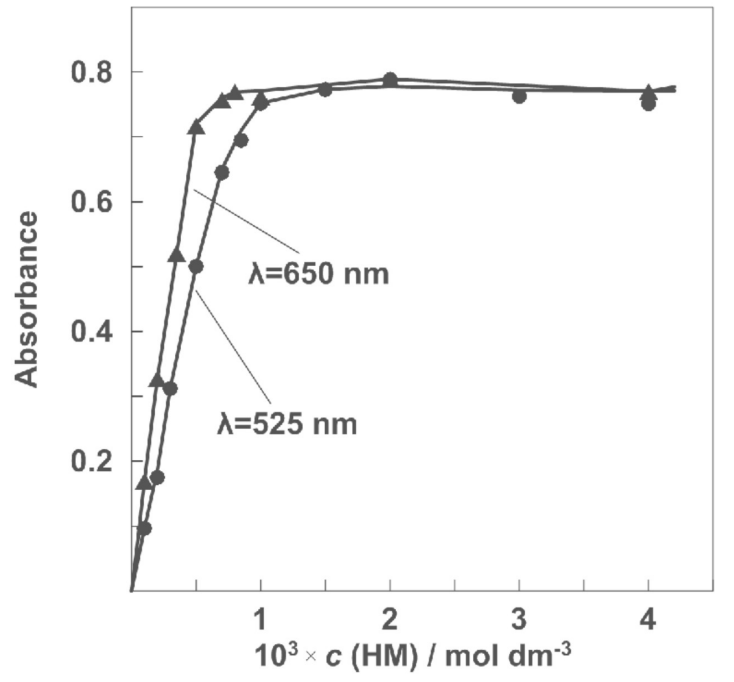

Figure 4. Effect of chloride and thiocyanate concentration on absorbance of $\mathrm{V}(\mathrm{V})-\mathrm{HM} . c(\mathrm{HM})=2 \times 10^{-3} \mathrm{~mol} \mathrm{dm}^{-3}$; $\mathrm{pH} 2$; • $c\{\mathrm{~V}(\mathrm{~V})\}=2 \times 10^{-4} \mathrm{~mol} \mathrm{dm}^{-3}$, varying concentration of chloride ions; $\boldsymbol{\Delta}\{\mathrm{V}(\mathrm{V})\}=1 \times 10^{-4} \mathrm{~mol} \mathrm{dm}^{-3}$, varying concentration of thiocyanate ions.

$1 \times 10^{-4} \mathrm{~mol} \mathrm{dm}^{-3}$, respectively. Using optimal concentration of HM in chloroform, maximal absorbance of organic phase was achieved if chloride concentration in aqueous phase was $2 \mathrm{~mol} \mathrm{dm}^{-3}$ and thiocyanate $2 \times 10^{-2}$ mol dm ${ }^{-3}$ respectively (Figure 4).

To check the proportionality between the vanadium concentration in the organic phase and the absorbance, solutions of $\mathrm{pH} 2$ and the vanadium(V) concentration varying from $2 \times 10^{-5}-3 \times 10^{-4} \mathrm{~mol} \mathrm{dm}^{-3}$ were extracted with the optimal concentration of HM in chloroform. Absorbance was measured at $525 \mathrm{~nm}$ in the presence of an excess of chloride ions $\left(2 \mathrm{~mol} \mathrm{dm}^{-3}\right)$ and at $650 \mathrm{~nm}$ in the presence of an excess of thiocyanate ions $\left(2 \times 10^{-2} \mathrm{~mol}\right.$

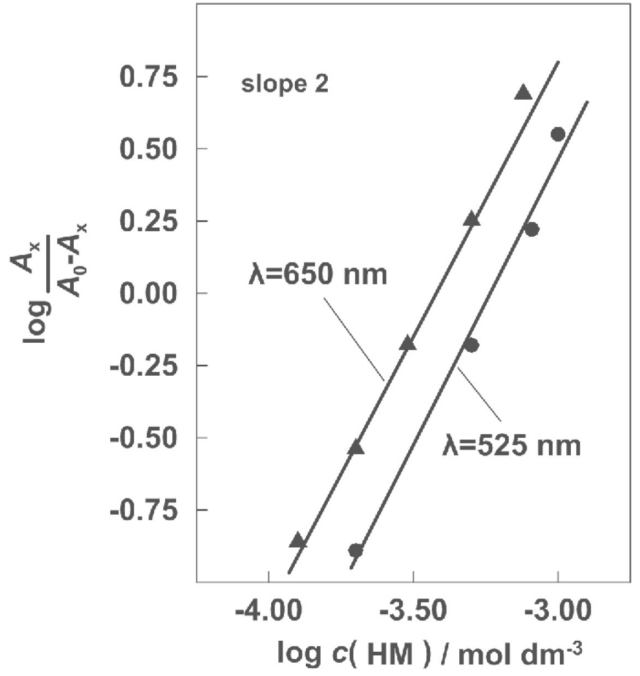

Figure 6. Analysis of the extraction data by the equilibrium shift method. $\mathrm{pH} 2 ; \bullet c\{\mathrm{~V}(\mathrm{~V})\}=2 \times 10^{-4} \mathrm{~mol} \mathrm{dm}^{-3}, c\left(\mathrm{Cl}^{-}\right)=2$ $\mathrm{mol} \mathrm{dm}{ }^{-3} ; \boldsymbol{\Delta} c\{\mathrm{~V}(\mathrm{~V})\}=1 \times 10^{-4} \mathrm{~mol} \mathrm{dm}^{-3}, c\left(\mathrm{SCN}^{-}\right)=2 \times 10^{-2}$ $\mathrm{mol} \mathrm{dm}{ }^{-3}$.

$\left.\mathrm{dm}^{-3}\right)$. The results show that Beer's Law is verified for the studied range of vanadium(V) concentrations. The value of the molar absorption coefficient for vanadium complex in the presence of chloride and thiocyanate ions is in the order of $4.1 \times 10^{3} \mathrm{~mol}^{-1} \mathrm{dm}^{3} \mathrm{~cm}^{-1}$ and $7.8 \times 10^{3}$ $\mathrm{mol}^{-1} \mathrm{dm}^{3} \mathrm{~cm}^{-1}$, respectively. Therefore, the complex formed in the presence of an excess of thiocyanate is more suitable for extraction and spectrophotometric determination of vanadium in the organic phase.

\section{Identification of Extractable Vanadium(V) Complexes}

The stoichiometric ratio between vanadium and HM and vanadium to thiocyanate was determined spectropho-
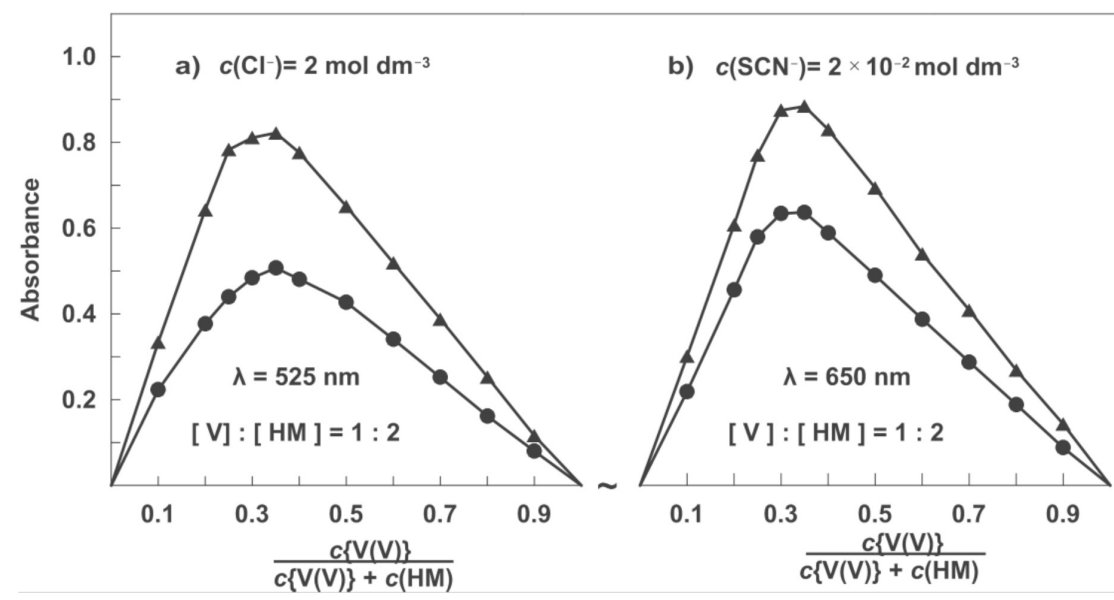

c) $c(\mathrm{HM})=2 \times 10^{-3} \mathrm{~mol} \mathrm{dm}^{-3}$

Figure 5. Determination of complex's composition by Job`s method. $\mathrm{pH} 2$; a) $c\left(\mathrm{Cl}^{-}\right)=2 \mathrm{~mol} \mathrm{dm}^{-3} ; \bullet c\{\mathrm{~V}(\mathrm{~V})\}+c(\mathrm{HM})=5 \times 10^{-4}$ $\left.\mathrm{mol} \mathrm{dm}{ }^{-3} ; \boldsymbol{\Delta} c\{\mathrm{~V}(\mathrm{~V})\}+c(\mathrm{HM})=7.5 \times 10^{-4} \mathrm{~mol} \mathrm{dm}^{-3} . \mathrm{b}\right) c\left(\mathrm{SCN}^{-}\right)=2 \times 10^{-2} \mathrm{~mol} \mathrm{dm}^{-3} ; \bullet c\{\mathrm{~V}(\mathrm{~V})\}+c(\mathrm{HM})=3 \times 10^{-4} \mathrm{~mol} \mathrm{dm}^{-3} ;$ $\left.c\{\mathrm{~V}(\mathrm{~V})\}+c(\mathrm{HM})=4 \times 10^{-4} \mathrm{~mol} \mathrm{dm}{ }^{-3} \cdot \mathrm{c}\right) \quad c(\mathrm{HM})=2 \times 10^{-3} \mathrm{~mol} \mathrm{dm}^{-3} ; \bullet c\{\mathrm{~V}(\mathrm{~V})\}+c\left(\mathrm{SCN}^{-}\right)=3 \times 10^{-4} \mathrm{~mol} \mathrm{dm}^{-3} ;$ $c\{\mathrm{~V}(\mathrm{~V})\}+c\left(\mathrm{SCN}^{-}\right)=4 \times 10^{-4} \mathrm{~mol} \mathrm{dm}^{-3}$. 
tometrically in the organic phase by Job's method of continuos variation. ${ }^{24}$ Mentioned spectrophotometric methods are not suitable for determining the number of moles of chloride per mole vanadium $(\mathrm{V})$ in the extracted complex because excess of chloride ions are needed for maximal absorbance of the organic phase. In the experiments for determination of molar ratio $\mathrm{V}: \mathrm{HM}$ the concentration of chloride or thiocyanate in aqueous phase was kept constant and in large excess. For determination of $\mathrm{V}: \mathrm{SCN}$ ratio the concentration of $\mathrm{HM}$ in chloroform was kept constant and in large excess. The results obtained by Job's method (Figure 5) indicated that the molar ratio of $\mathrm{V}(\mathrm{V})$ to $\mathrm{HM}$ is $1: 2$ and $\mathrm{V}(\mathrm{V})$ to $\mathrm{SCN}$ is $1: 1$.

The molar ratio of vanadium(V) to $\mathrm{HM}$ was also studied by distribution methods (slope analysis). ${ }^{25}$ The results obtained by plotting $\log \left[A_{\mathrm{x}} /\left(A_{0}-A_{\mathrm{x}}\right)\right] v s$. $\log$ $c(\mathrm{HM})$ (Figure 6), were in accordance with those obtained by Job's method. This confirmed that the molar ratios of vanadium $(\mathrm{V})$ to $\mathrm{HM}$ in the extracted complexes was 1:2.

In diluted solutions monomeric species of vana$\operatorname{dium}(\mathrm{V})$ are predominant. At $\mathrm{pH}$ values lower than 3, the cationic form $\mathrm{VO}_{2}{ }^{+}$can be present in the solution. ${ }^{26}$ Since in the experiments of vanadium extraction described here its concentration was low, and the concentration of hydrogen ions was rather high, presence of chloride or thiocyanate ions could result in formation of mixed complexes which can be extracted with HM in the organic phase. For that reason, and on the basis of previously published results about extraction of vanadium with some pyridin-4-one derivatives ${ }^{27}$ it can be assumed that $\mathrm{VO}_{2} \mathrm{Cl}(\mathrm{HM})_{2}$ or $\mathrm{VO}_{2} \mathrm{SCN}(\mathrm{HM})_{2}$ is formed and transferred into the organic phase.

\section{CONCLUSION}

The optimal reaction conditions, $24 \mathrm{~h}$ and $p-\mathrm{TsOH}$ as an acid catalyst, were determined in the preparation of 3-hydroxy-1-( $p$-methoxyphenyl)-2-methylpyridine-4one (HM) in one step synthesis leading to the most satisfactory yield $(63 \%)$. The application of HM for the extraction of $\mathrm{V}(\mathrm{V})$ in chloroform was investigated. It was found that the sensitivity of the reaction of vanadium(V) with $\mathrm{HM}$ is considerably increased when excess of chloride or thiocyanate ions is present during extraction. At pH 2 and in presence of chloride ions (2 mol $\mathrm{dm}^{-3}$ ) an orange complex of the maximal absorbance at $525 \mathrm{~nm}$ was formed. However, the vanadi$\mathrm{um}(\mathrm{V})$ complex formed at the same $\mathrm{pH}$ value in the presence of an excess of thiocyanate ions $\left(2 \times 10^{-2} \mathrm{~mol}\right.$ $\mathrm{dm}^{-3}$ ) can be extracted with $\mathrm{HM}$ in chloroform as a green complex which has a maximum absorbance at 440 and $650 \mathrm{~nm}$. The results obtained indicate that molar ratio $\mathrm{V}: \mathrm{SCN}(\mathrm{Cl})$ : $\mathrm{HM}$ of the extracted com- plex is 1:1:2 and most probably $\mathrm{VO}_{2} \mathrm{Cl}(\mathrm{HM})_{2}$ or $\mathrm{VO}_{2} \mathrm{SCN}(\mathrm{HM})_{2}$ complex is formed and transferred into the organic phase.

Acknowledgements. We wish to thank the Ministry of Science, Education and Sports of the Republic of Croatia for support of this work (projects 119-1191342-2959 and 119-11913443121).

\section{REFERENCES}

1. M. A. Santos, S. M. Marques, and S. Chaves, Coord. Chem. Rev. 256 (2012) 240-259.

2. Y. Ma, T. Zhou, X. Kong, and R. C. Hider, Curr. Med. Chem. 19 (2012) 2816-2827.

3. L. Saghaie and R. C. Hider, Res. Pharm. Sci. 3 (2008) 21-30.

4. L. Saghaie, M. Mirmohammad Sadeghi, and A. Nikazama, Res. Pharm. Sci. 1 (2006) 40-48.

5. M. A. Santos, M. Gil, L. Gano, and S. Chaves, J. Biol. Inorg. Chem. 10 (2005) 564-580.

6. L. E. Scott and C. Orvig, Chem. Rev. 109 (2009) 4885-4910.

7. A. Fassihi, D. Abedi, L. Saghaie, R. Sabet, H. Fazeli, G. Bostaki, O. Deilami, and H. Sadinpour, Eur. J. Med. Chem. 44 (2009) 2145-2157.

8. L. S. Dehkordi, Z. D. Liu, and R. C. Hider, Eur. J. Med. Chem. 43 (2008) 1035-1047.

9. D. S. Kalinowski and D. R. Richardson, Pharm. Rev. 57 (2005) 547-583.

10. Z. Zhang, S. J. Retting, and C. Orvig, Can. J. Chem. 70 (1992) $763-770$.

11. A. G. Ivšić, V. Tomišić, Ž. Car, B. Prugovečki, and S. Tomić, J. Mol. Str. 990 (2011) 237-243.

12. B. Gummow, Vanadium: Enviromental Pollution and Health Effects, in: Encyclopedia of Environmental Health, Elsevier, 2011, p. 628-636.

13. W. R. Harris, S. B. Friedman, and D. Silberman, J. Inorg. Biochem. 20 (1984) 157-169.

14. K. H. Thompson, J. Lichter, C. LeBel, M. C. Scaife, J. H. McNeill, and C. Orvig, J. Inorg. Biochem. 103 (2009) 554-558.

15. M. Rangel, M. J. Amorim, A. Nunes, A. Leite, E. Pereira, B. de Castro, C. Sousa, Y. Yoshikawa, and H. Sakurai, J. Inorg. Biochem. 103 (2009) 496-502.

16. M. D. Waters, Toxicology of Vanadium, in: R. A. Goyer and M. A. Mehlman (Eds.), Toxicology of Trace Metals, Wiley, New York, 1977, p. 147-189.

17. K. Pyrzynska, Microchim. Acta 149 (2005) 159-164.

18. M. Mishra, R. Mathur, and R. K. Gautam, Glo. Adv. Res. J. Microbiol. 2 (2013) 17-21.

19. K. Jakopčić, B. Tamhina, F. Zorko, and M. J. Herak, J. Inorg. Nucl. Chem. 39 (1977) 1201-1203.

20. B. Tamhina, K. Jakopčić, F. Zorko, and M. J. Herak, J. Inorg. Nucl. Chem. 36 (1974) 1855-1857.

21. A. Budimir, T. Benković, V. Tomišić, A. Gojmerac Ivšić, and N. Galić, J. Solution. Chem., in press.

22. I. M. Kolthof and P. J. Elving, Treatise on Analytical Chemistry, II/8 Interscience, New York, 1963, p. 222.

23. R. L. N. Harris, Aust. J. Chem. 29 (1976) 1329-1334.

24. P. Job, Ann. Chim. Phys. 8 (1928) 113-203; J. S. Renny, L. L. Tomasevich, E. H. Tallmadge, and D. B. Collum, Angew. Chem. Int. Ed. 52 (2013) 11998-12103.

25. H. Puzanowska-Tarasiewicz, A. Grudniewska, and M. Tarasiewicz, Anal. Chim. Acta 94 (1977) 435-441.

26. F. A. Cotton, G. Wilkinson, C. A. Murillo, and M. Bochmann, 
Advanced Inorganic Chemistry, $6^{\text {th }}$ edition, J. Willey \& Sons, Inc. New York, 1999, p.720.
27. B. Tamhina, V. Vojković, and M. J. Herak, Microchem. J. 25 (1980) 8-13. 